\title{
Prevention of diabetes mellitus in non-obese diabetic mice by Linomide, a novel immunomodulating drug
}

\author{
D.J. Gross ${ }^{1}$, H. Sidi ${ }^{2 ;}$, L. Weiss ${ }^{2}$, T. Kalland ${ }^{4}$, E. Rosenmann ${ }^{3}$, S. Slavin ${ }^{2}$ \\ ${ }^{1}$ Department of Endocrinology and Metabolism, Hadassah University Hospital, Jerusalem, Israel \\ ${ }^{2}$ Department of Bone Marrow Transplantation and Cancer/Immunobiology Research Laboratory, Hadassah University Hospital, \\ Jerusalem, Istael \\ ${ }^{3}$ Department of Pathology, Hadassah University Hospital, Jerusalem, Israel \\ ${ }^{4}$ Pharmacia, Oncology Immunology, Scheelevägen 22, S-223 63 Lund, Sweden
}

Summary Oral administration of the synthetic immunomodulating drug quinoline-3-carboxamide (Linomide) in the drinking water to 5-week-old female non-obese diabetic (NOD) mice resulted in complete protection from insulitis and maintenance of normal glucose tolerance for over 40 weeks (impaired glucose tolerance: treated $n=2$ of 18 ; control $n=17$ of $18, p<0.0001$ ). Delayed administration of the drug at 16 weeks resulted in slowing of the progression to diabetes when assessed at 42 weeks (treated with diabetes $n=7$ of 25 ; control with diabetes 25 of $43, p<0.0234$ ). No gross changes of immune system cell phenotype or function were observed in the Linomide-treated group. Adoptive transfer of spleen and lymph node cells from treated female NOD mice into sub-lethally irradiated male recipients failed to transfer diabetes, whereas a similar transfer of cells obtained from untreated age-matched controls resulted in diabetes in all secondary recipients (diabetes in control group $n=12$ of 13 ; in Linomide group $n=0$ of $11, p<0.0001$ ). Linomide pre- treatment of the secondary recipients also inhibited the transfer of diabetes (diabetes in pretreated group $n=2$ of 9 , control group $n=12$ of $13, p<0.015$ ), as did adoptive co-transfer of cell mixtures obtained from treated female NOD mice, free of diabetes, and from diabetic NOD female mice (diabetes in Linomide group $n=4$ of 9 ; in control group 7 of 7 , $p<0.0337$ ). Our data indicate that Linomide-treated NOD mice generate immune cells with the capacity to downregulate responses to beta-cell antigens, apparently through immunoregulation rather then antigen non-specific immunosuppression. Based on our findings and considering the lack of severe side effects of orally administered Linomide in man, this new compound should be considered as a potential drug for treatment of insulin-dependent diabetes mellitus. [Diabetologia (1994) 37: 1195-1201]

Key words Autoimmunity, immunomodulation, insulin-dependent diabetes mellitus, non-obese diabetic mouse.
Received: 25 March 1994

and in revised form: 13 June 1994

Corresponding author: Dr. S. Slavin, Department of Bone Marrow Transplantation and Cancer/Immunobiology Research Laboratory, Hadassah University Hospital, P.O.B. 12000, Jerusalem, Israel 91120

Abbreviations: IDDM, Insulin-dependent diabetes mellitus; NK, natural killer; IL, interleukin; NOD, non-obese diabetic; IPGTT, intraperitoneal glucose tolerance test; FITC, fluorescein-5-isothiocyanate; DTAF, 5(4,6 dichlorotriazinyl) aminofluorescein; FACS, fluorescein activated cell sorting; PHA, phythaemagglutinin; Con A, concanavalin A; SEA, staphylococcal extract A; SEB, staphylococcal extract B; SRBC, sheep erythrocytes; HBSS, Hanks buffered salt solution; LPS, lipopo-
Insulin-dependent diabetes mellitus (IDDM) is characterized by immune-mediated progressive destruction of the pancreatic beta cells by auto-reacting lymphocytes. An obvious therapeutic approach would be intervention directed against the autoimmune process, with reinduction of tolerance towards self antigens at an early stage of the disease, aimed at preserving a critical mass of pancreatic beta cells necessary for maintenance of normal glucose tolerance.

lysaccharide; MLR, mixed lymphocyte reaction; DTH, delayed-type, hypersensitivity; BCG, Bacillus Calmette Guerrin; APC, antigen presenting cell; TNF- $\alpha$, tumor necrosis factor- $\alpha$. 
Linomide (quinoline-3-carboxamide, Roquinimex, LS 2616), is a novel, orally absorbed, immunomodulatory drug that increases the number and function of activated natural killer (NK)-cells $[1,2]$ enhances delayed type hypersensitivity reactions [3] and increases lymphocyte proliferation in response to T-cell-dependent mitogens accompanied by an enhanced production of interleukin-2 (IL-2) [4]. Moreover, Linomide has been shown to have a potent ameliorative effect in a variety of murine models of human autoimmune disease such as the systemic lupus erythematosus-like syndrome [5, 6] type II collagen induced arthritis [7], and experimental autoimmune encephalomyelitis [8]. In this report, we studied the effect of long-term oral administration of Linomide on the course of insulitis and diabetes in the non-obese-diabetic (NOD) mouse, a well-characterized mouse strain that serves as a model for human IDDM.

\section{Materials and methods}

Mice. Male and female NOD mice were obtained from Bomholtgård (Laven, Denmark) and BALB/c mice were bred locally. All mice were maintained in a regular animal facility at $21^{\circ} \mathrm{C}$ with acidified water ( $\left.\mathrm{pH} 2.7\right)$ and mouse chow ad libitum.

Experimental conditions. Linomide (supplied by Pharmacia, Lund, Sweden) was administered at a dose of $0.5 \mathrm{mg} / \mathrm{ml}$ in drinking water to five or 16 -week-old female NOD mice, the control groups received regular water. With an average $( \pm \mathrm{SD}$ ) initial fluid intake of $2.9 \pm 0.3 \mathrm{ml} /$ day that was maintained throughout the experiments, the Linomidetreated mice received an initial drug dosage of $82.7 \pm 7.7 \mathrm{mg}$. $\mathrm{kg}^{-1} \cdot$ day $^{-1}$ that declined (coincident to weight gain) to $58.3 \pm 11.8 \mathrm{mg} \cdot \mathrm{kg}^{-1} \cdot \mathrm{day}^{-1}$ at 40 weeks of age. Subsequent experimental groups received Linomide at a lower dosage $(0.1$ and $0.02 \mathrm{mg} / \mathrm{ml}$ ) and for limited periods: 5 weeks (5 to 10 weeks of age) and 15 weeks ( 5 to 20 weeks). The level of urine glucose (Labstix; Bayer Diagnostics, Puteaux-Cedex, France), weight and fluid intake were determined on a biweekly basis. The onset of diabetes was defined after the appearance of glucosuria on two consecutive determinations. In the initial experiments representative animals were killed at 12 weeks of age for histopathological examination; spleen and lymph node cells were harvested for characterization of mononuclear cell phenotype, in vitro proliferative responses and cytolytic activity. At age 16 weeks an intraperitoneal glucose tolerance test (IPGTT) was performed as follows: blood was drawn from the paraorbital plexus at $0 \mathrm{~min}$ and $60 \mathrm{~min}$ after the i.p. injection of glucose, $1 \mathrm{~g} / \mathrm{kg}$ body weight. Plasma glucose levels were determined with a Glucose Analyzer 2 (Beckman Instruments, Fullerton, Calif., USA). At 40 weeks of age an additional IPGTT was done and the following day animals were killed for histopathological evaluation and for various assays as described for age 12 weeks.

Histopathology. Pancreatic tissue was fixed in $10 \%$ formalin, embedded in paraffin and thin sections were stained with haematoxylin and cosin. Sections containing a total of 25 islets from each pancreas were reviewed and scored on a blind basis according to the method of Charlton et al. [9]. Briefly, 25 islets from each pancreas were scored according to the following grading system: 0 - normal islet; 1 - peri-insulitis $<25 \%$ of circumference; 2 - peri-insulitis $>25 \%$ of circumference; 3 -insulitis penetrating the islet; 4 - pan-insulitis with no evidence of normal islet cells. The sum of scores of each pancreas is expressed as a percentage: $0 \%$ - normal islets, $100 \%$ - pan-insulitis involving all islets. Other internal organs were examined for signs of drug toxicity.

Mononuclear cell phenotype characterization. Cell surface phenotype of spleen and lymph node cells obtained from control (untreated) and Linomide treated $(0.5 \mathrm{mg} / \mathrm{ml}$ in drinking water) female NOD mice was determined as follows: Aliquots of $2 \times 10^{6}$ cells were incubated with each of the following antibodies: fluorescein activated cell sorting (FITC) conjugated antimouse CD3- $\varepsilon$ monoclonal antibody, FITC conjugated rat antimouse L3T4 (CD4) monoclonal antibody, R-phycoerythrin conjugated rat anti-mouse Lyt-2 (CD8a) monoclonal antibody, phycoerythrin conjugated mouse anti-mouse NK-cell specific monoclonal antibody (all purchased from Pharmingen, San Diego, Calif., USA), fluorescein (DTAF) conjugated affinipure $\mathrm{f}(\mathrm{ab})^{\prime} 2$ fragment goat anti-mouse $\operatorname{IgG}, \mathrm{f}(\mathrm{ab})^{\prime} 2$ fragment specific (Jackson Immunoresearch Laboratories Inc., Baltimore, Md., USA), rat monoclonal antibody to murine type 3 complement receptor MCA 711 (Serotec, Oxford, UK). Cells were washed with ice-cold phosphate buffered saline containing $1 \%$ sodium azide and all incubations and washes were carried out at $4^{\circ} \mathrm{C}$. Freshly stained cells were analysed by FACS (FACStar plus, Becton-Dickenson, San Jose, Calif., USA). Background fluorescence was determined with cells alone.

Mononuclear cell function assessment. The following in vitro responses of pooled spleen and lymph node cells were determined: proliferative responses to T-cell dependent mitogens: PHA (Wellcome, Beckenham, UK) Con A (Sigma St. Louis, Mo., USA), recombinant human IL-2 (a gift from Dr. C.R. Franks. Eurocetus, the Netherlands), IL-4 (as supernatant of mouse cell lines engineered to constitutively secrete the cytokine [11]) and staphylococcal extract A and B (SEA and SEB) (provided by Pharmacia, Lund, Sweden) as well as to B-cell dependent mitogens: lipopolysaccharide (LPS) (Difco, Detroit, Mich., USA), and alloantigens (one-way mixed lymphocyte reaction (MLR) against irradiated $[3000 \mathrm{cGy}] \mathrm{C}_{3} \mathrm{H} / \mathrm{HeJ}$ cells). Cells were cultured in RPMI 1640 medium supplemented with $10 \%$ heat-inactivated human $\mathrm{AB}$ serum in $0.2 \mathrm{ml}$ flat-bottomed microtitre plates containing $4 \times 10^{5}$ cells/well and responses were assessed by ${ }^{3} \mathrm{H}$-thymidine uptake as described [10]. IL-2 dependent cytolytic activity was tested against ${ }^{51} \mathrm{Cr}$ labelled NK sensitive (YAC-1) and NK resistant (p815) target cells [11]. Inhibition of T-cell dependent responses to phythaemagglutinin (PHA) or allogeneic lymphocytes $(\mathrm{C} 3 \mathrm{H} / \mathrm{HeJ})$ was assayed by adding irradiated and non-irradiated NOD lymphocytes in mixed lymphocyte co-cultures [12].

Adoptive transfer. In preliminary calibration experiments it was possible to adoptively transfer diabetes to sublethally irradiated (550 cGy) male recipients with 10,20 , and $30 \times 10^{6}$ cells, therefore this range of inocula has full potential for induction of the disease. Twenty to $30 \times 10^{6}$ spleen and lymph node cells were obtained from 30 -week-old diabetic or age-matched Linomide treated $(0.5 \mathrm{mg} / \mathrm{ml})$ female NOD mice and injected i. v. into male recipient mice 1 day after sublethal irradiation whole body ( $550 \mathrm{cGy}$ ). Another group of male recipients from female diabetic donors were either pretreated with Linomide $(0.5 \mathrm{mg} / \mathrm{ml})$ for 8 weeks or put on the drug after the procedure. In co-transfer experiments, $20 \times 10^{6}$ cells from diabetic mice were mixed with either $20 \times 10^{6}$ or $40 \times 10^{6}$ cells from 
a

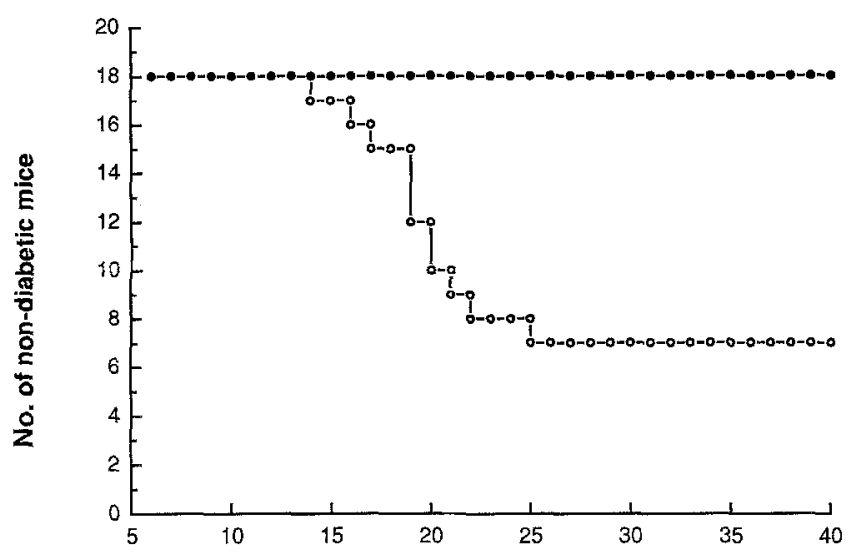

b

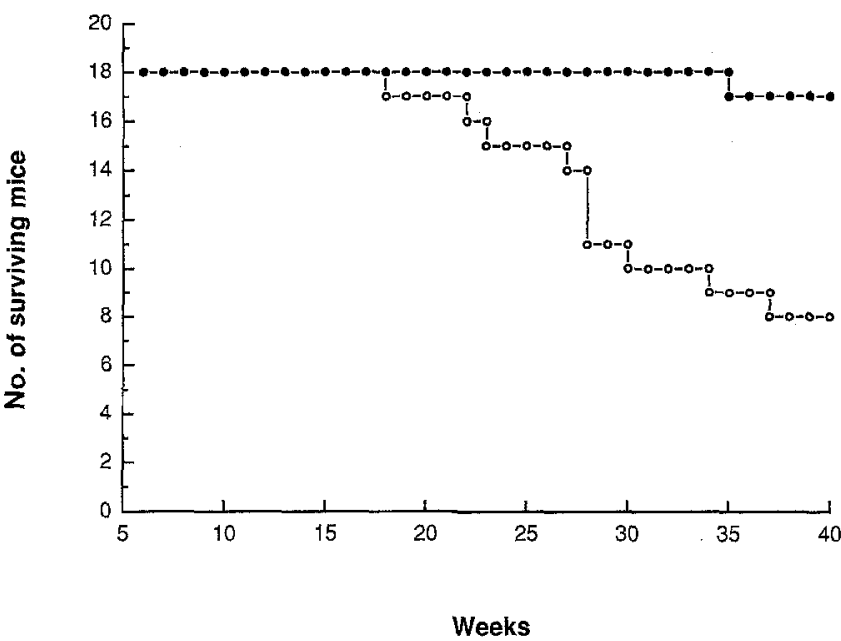

Fig. 1a, b Cumulative incidence of diabetes (a) and mortality (b) in female NOD control (O) and Linomide-treated mice $(0.5 \mathrm{mg} / \mathrm{ml}$ in drinking water starting from week 5 , $)$ followed for 40 weeks. The differences between the two groups were highly significant (diabetes $p<0.0001$; mortality $p<0.0027$ ). The presence of diabetes was ascertained on the basis of at least two consecutive determinations of glucosuria greater than $111 \mathrm{mmol} / \mathrm{l}$. The single death in the treatment group was not due to diabetes

Linomide-treated donors. $\mathrm{T}$ cells from diabetic mice were prepared by pre-adhering the cell suspension on plastic dishes for $2 \mathrm{~h}$ at room temperature and passage of non-adherent cells through a nylon wool column.

Delayed-type hypersensitivity responses. DTH responses to sheep erythrocytes (SRBC) were determined 1 week after immunization with $5 \times 10^{5}$ SRBC HBSS injected i.v. to diabetic and age-matched Linomide-treated female NOD mice. The left anterior footpad was injected with $5 \times 10^{8} \mathrm{SRBC}$ in $\mathrm{NaCl}$ and the contralateral foot pad was injected with $\mathrm{NaCl}$ alone. After $24 \mathrm{~h}$ footpad thickness was measured with a micrometer and regional lymph node cell proliferative responses were determined as previously described [13]. Net responses were derived by subtracting control $(\mathrm{NaCl})$ values from $\mathrm{SRBC}$ values and expressed in $\mathrm{mm}$ and ${ }^{3} \mathrm{H}$-thymidine incorporation in $\mathrm{cpm}$ for the two parameters, respectively.
Statistical analysis

Student's two tailed $t$ test was used for the comparison of means of experimental groups; Fisher's exact test was used for contingency table analyses.

\section{Results}

Occurrence of diabetes. Groups of female NOD mice were treated with Linomide $0.5 \mathrm{mg} / \mathrm{ml}$ in drinking water starting at 5 weeks of age. Figure 1 a shows the cumulative appearance of diabetes in treated mice in comparison with untreated controls. As expected, at approximately 15 weeks of age, untreated animals started to develop diabetes, reaching a cumulative incidence of $61 \%$ at 40 weeks. In sharp contrast, the Linomide-treated group remained free of diabetes throughout the duration of the experiment. At the end of these experiments, there was a significant decrease in the weight of the mice in the treated groups (treated $22.7 \pm 2.6 \mathrm{~g}$; control $25.9 \pm 2.8 \mathrm{~g}, \mathrm{p}<0.0006$ ); however, they appeared well and remained alive (Fig. 1b). Detailed histological examination of skin, brain, heart, lungs, liver, kidneys, and small and large bowel revealed no evidence of drug toxicity. In order to obtain better assessment of metabolic control, IPGTTs were done at 16 weeks (data not shown) and 40 weeks of age (Fig.2): with the exception of two mice, the Linomide-treated group demonstrated a normal tolerance test indistinguishable from normal control BALB/c mice, whereas the vast majority of the surviving untreated mice were either diabetic or severely glucose intolerant (Fig.2).

Effect of Linomide dosage and duration of treatment. In subsequent experiments, we assessed the effect of Linomide dosage, duration of treatment and delayed drug administration on the incidence of diabetes: $\mathrm{Li}^{-}$ nomide, given at either a lower dosage $(0.1$ and 0.02 $\mathrm{mg} / \mathrm{ml}$ ) or at a dose of $0.5 \mathrm{mg} / \mathrm{ml}$ for limited periods of 5 or 15 weeks at the onset ( 5 weeks of age), resulted in protection from diabetes (Table 1). In order to assess whether Linomide was effective after the onset of insulitis, we assessed the incidence of diabetes in mice receiving the drug only from 16 weeks of age (as expected, no glucosuria was noted at this age). This regimen resulted in a marked delay in the appearance of the disease, with a cumulative incidence after 42 weeks of $28 \%$ in comparison to $58 \%$ in the control group (Table 1).

Pancreatic histology. Histological examination of the pancreas (done in a blinded manner by E.R.) at 12 and 40 weeks of age revealed a paucity of islets, the surviving islets being afflicted with typical insulitis in all untreated mice. In the two Linomide-treated, glucose intolerant mice (Fig.2), both peri-insulitis in 


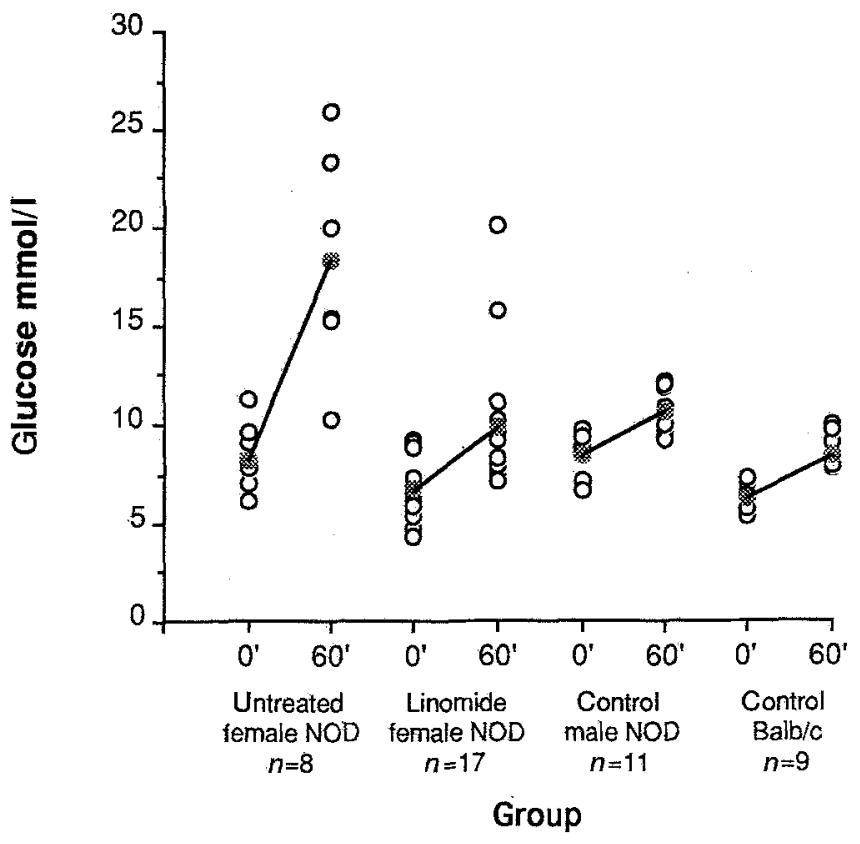

Fig. 2. Intraperitoneal glucose tolerance test $(1 \mathrm{~g} / \mathrm{kg}$ body weight glucose given before and 60 min after blood sampling from the orbital capillary plexus) done in surviving untreated control female NOD mice at 40 weeks, Linomide-treated female NOD mice at 40 weeks $(0.5 \mathrm{mg} / \mathrm{ml}$ in drinking water from week 5), untreated male NOD control mice (5 weeks of age) and control BALB/c mice. The basal glucose values were significantly elevated in the untreated female NOD controls (untreated vs Balb/c $p<0.013$ ), but not in the Linomide-treated group (Linomide vs Balb/c- N.S.). The mean 60-min glucose values were the same for the Linomide-treated females, male NOD and Balb/c groups and significantly higher in the untreated female NOD controls (untreated ys male NOD, $p<0.012$ ). Plasma glucose levels were determined by the glucose oxidase method. Lines connecting stippled circles depict mean values

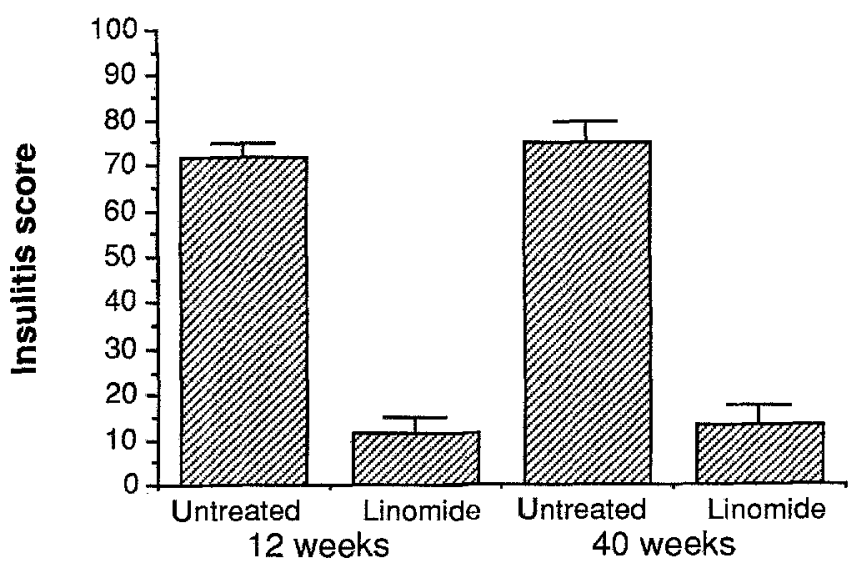

Fig. 3. Semi-quantitative assessment of insulitis severity (score $\pm \mathrm{SEM}$ ) in Linomide-treated $(0.5 \mathrm{mg} / \mathrm{ml}$ in drinking water from week 5) and untreated control mice at 12 weeks (control $n=6$; Linomide $n=6, p<0.001$ ) and 40 weeks (controls $n=8$; Linomide $n=17, p<0.001$ ). The 12 and 40 week scores of both the control and Linomide-treated groups did not differ significantly
Table 1. The effect of Linomide dosage, duration of treatment and timing of treatment and on the cumulative incidence of diabetes in female NOD mice at 42 weeks of age

\begin{tabular}{lll}
\hline Linomide dosage & $\begin{array}{l}\text { Incidence and (\%) of } \\
\text { diabetes at 42 weeks }\end{array}$ & $p$ value $^{\mathrm{a}}$ \\
\hline Control (untreated): & $25 / 43(58)$ & - \\
$0.5 \mathrm{mg} / \mathrm{ml}$ (weeks 5-42) & $0 / 18(0)$ & $<0.0001$ \\
$0.1 \mathrm{mg} / \mathrm{ml}$ (weeks 5-42) & $0 / 17(0)$ & $<0.0001$ \\
$0.02 \mathrm{mg} / \mathrm{ml}$ (weeks 5-42) & $1 / 20(5)$ & $<0.0001$ \\
$0.5 \mathrm{mg} / \mathrm{ml}$ (weeks 5-10) & $2 / 10(20)$ & $<0.0394$ \\
$0.5 \mathrm{mg} / \mathrm{ml}$ (weeks 5-20) & $2 / 10(20)$ & $<0.0394$ \\
$0.5 \mathrm{mg} / \mathrm{ml}$ (weks 16-42) & $7 / 25(28)$ & $<0.0234$ \\
\hline
\end{tabular}

${ }^{a}$ Compared to control group, Fisher's exact test

Each row depicts the summary of an individual experiment, excluding the control data that was pooled from three experiments. Values in parentheses denote the duration and timing of drug administration

some islets and pan-insulitis in others were observed. However, most treated animals showed islets predominantly normal in size, number and morphology; there was only occasional mild peri-insulitis in a minority of islets, reflected by the semi-quantitative insulitis score shown in Fig. 3.

Spleen and lymph node mononuclear cell phenotype. We compared the phenotype of spleen and lymph node cells obtained at 40 weeks of age from Linomide-treated and age-matched untreated controls. FACS analysis showed no significant difference in the expression of cell surface CD3, CD4, CD8, Bcells, MAC-1 cells and NK cells (Table 2).

In vitro cell mediated proliferative responses. Functional in vitro studies of cell-mediated proliferative responses assessed by ${ }^{3} \mathrm{H}$-thymidine uptake in response to T-cell dependent mitogens (PHA, Con A, IL-2, IL-4, SEA and SEB), B-cell dependent mitogen (LPS) and MLR showed no differences between Linomide-treated and control NOD mice (Table 3 and data not shown). Likewise, IL-2-induced cytolytic responses against ${ }^{51} \mathrm{Cr}$-labelled $\mathrm{NK}$ sensitive (YAC-1) and NK resistant (p815) target cells at 40 weeks of age revealed no significant differences between Linomide-treated mice $(0.5 \mathrm{mg} / \mathrm{ml}$ and 2.5 $\mathrm{mg} / \mathrm{ml}$ ) in comparison with untreated age-matched controls (data not shown). Irradiated and non-irradiated splenocytes obtained from Linomide-treated NOD mice did not block T-cell dependent proliferative responses to either PHA or allogeneic lymphocytes $(\mathrm{C} 3 \mathrm{H} / \mathrm{HeJ})$ in mixed lymphocyte co-cultures when mixed in equal proportions to the responding effector cells (data not shown).

Delayed type hypersensitivity ( $D T H$ ) responses. DTH responses to SRBC were determined in untreated (control) and Linomide-treated $(0.5 \mathrm{mg} / \mathrm{ml})$ female NOD mice. Both groups showed a wide inter-subject 
Table 2. Representative experiment of cell surface phenotype of spleen cell and lymph node cells obtained froma control (untreated) and Linomide-treated $(0.5 \mathrm{mg} / \mathrm{ml}$ in drinking water) female NOD mice at 40 weeks. of age. The present and subsequent experiments (data not shown), showed no significant trends

\begin{tabular}{|c|c|c|c|c|c|c|}
\hline & $\mathrm{CD} 3$ & $\mathrm{CD} 4$ & $\mathrm{CD} 8$ & B-cells & Mac-1 & NK cells \\
\hline Untreated: & $20.4 \pm 2.8$ & $10.3 \pm 4.2$ & $7.6 \pm 1.2$ & $27.1 \pm 4.5$ & $4.4 \pm 0.6$ & $3.3 \pm 0.3$ \\
\hline Linomide: & $25.2 \pm 4.1$ & $17.4 \pm 2.5$ & $8.7 \pm 1.5$ & $30.9 \pm 2.2$ & $2.9 \pm 0.3$ & $2.1 \pm 0.3$ \\
\hline
\end{tabular}

Data presented as mean \pm SD

Table 3. In vitro proliferative responses of spleen and lymph node cells to mitogens in control and Linomide-treated $(0.5 \mathrm{mg} / \mathrm{ml}$ in drinking water) female NOD mice

\begin{tabular}{|c|c|c|c|c|}
\hline \multirow[b]{3}{*}{ Stimulating agent } & \multicolumn{4}{|c|}{${ }^{3} \mathrm{H}$ thymidine uptake $(\mathrm{cpm} \pm \mathrm{SD})^{\mathrm{a}}$} \\
\hline & \multicolumn{2}{|l|}{ Untreated } & \multicolumn{2}{|c|}{ Linomide-treated } \\
\hline & Basal & Stimulated & Basal & Stimulated \\
\hline $\operatorname{Con} \mathrm{A}(10 \mu \mathrm{g} / \mathrm{ml})^{\mathrm{b}}$ & " & $212,514 \pm 24,733$ & 4 & $195,167 \pm 19,042$ \\
\hline $\operatorname{SEA}(1 \mu \mathrm{g} / \mathrm{ml})^{\mathrm{b}}$ & “ & $61,482 \pm 7,817$ & “ & $79,314 \pm 11,402$ \\
\hline $\operatorname{SEB}(1 \mu \mathrm{g} / \mathrm{ml})^{\mathrm{b}}$ & $“$ & $16,121 \pm 1,017$ & " & $32,896 \pm 7,513$ \\
\hline L.PS $(50 \mu \mathrm{g} / \mathrm{ml})^{\mathrm{c}}$ & “ & $23,033 \pm 4,324$ & “ & $18,078 \pm 3,570$ \\
\hline
\end{tabular}

${ }^{a}$ Representative experiments (of two or three experiments) on cell samples pooled from three animals from each treatment group. There were no significant differences between the untreated and treated groups. Additional data obtained at
16 weeks of age again did not demonstrate any differences of mitogen responses between the two groups (data not shown). ${ }^{b}$ After 1 week of treatment. ${ }^{c}$ Determined at the end of the experiments at 40 weeks of age variation. Net footpad thickness was $0.38 \pm 0.16 \mathrm{~mm}$ in controls vs $0.48 \pm 0.14 \mathrm{~mm}$ in the Linomide-treated group. ${ }^{3} \mathrm{H}$-thymidine incorporation in the lymphocyte proliferation assay was $305 \pm 332 \mathrm{cpm}$ (mean \pm SEM) in controls $(n=8)$ vs $335 \pm 221 \mathrm{cpm}$ in Linomide-treated mice $(n=9)$. There were no significant differences between the two groups.

Adoptive transfer of diabetes. Mixtures of spleen and lymph node cells or purified $\mathrm{T}$ cells obtained from diabetic mice injected i.v. into sub-lethally irradiated male NOD recipients resulted in diabetes appearing between days 20 to 60 approximately, with a cumulative incidence of $92 \%$ at 100 days (Table 4 , groups A-C). In contrast, a similar adoptive transfer of cells obtained from normoglycaemic, Linomide-treated female NOD mice did not result in any evidence of diabetes (as determined by glucosuria) during the same observation period (Table 4, group D). Adoptive transfer of spleen and lymph node cell mixtures obtained from a pool of untreated, diabetic female NOD mice into male recipients that were placed on Linomide therapy starting from the date of cell transfer did not confer protection (Table 4, group $\mathrm{E}$ and F). In contrast, male recipients pretreated with Linomide for 10 weeks prior to cell transfer were protected from diabetes as compared with untreated male recipient controls that received similar inocula (Table 4, group G). Adoptive co-transfer of $20 \times 10^{6}$ cells from diabetic and Linomide-treated female mice at a 1:1 ratio did not alter the course of the dis- ease (Table 4, group $\mathrm{H}$ ). However, when the inoculum from the Linomide-treated mice was increased to $40 \times 10^{6}$ cells, (2:1 ratio, Linomide vs diabetic) diabetes was suppressed in more than $50 \%$ of the animals, in comparison to $100 \%$ in the control group (Table 4, groups I vs J).

\section{Discussion}

The data presented suggest that in the NOD mouse, prevention of autoimmune insulitis and diabetes can be accomplished by oral administration of Linomide without significant side effects. Although the details of the mechanism of Linomide action on the autoimmune process are yet unknown, sustained antigen non-specific immunosuppressive effects were ruled out by comparable cell surface phenotype, in vitro responses of mononuclear cells to T- and B-cell dependent mitogens and mixed lymphocyte reaction, cytotoxicity assays against NK-sensitive and NK-resistant target cells as well as the in vivo DTH responses in treated and control mice. Establishment of unresponsiveness to self antigens by Linomide, as confirmed by the adoptive transfer experiments, in the presence of normal or even enhanced T-cell dependent mitogenic responses, suggests that Linomide may be effective for immunoregulation of self-reactive lymphocytes. The inhibition of diabetes in Linomide-pretreated secondary adoptive recipients of spleen and lymph node cells derived from diabetic 
Table 4. Effect of adoptive transfer of spleen and lymph node cells on the incidence of diabetes in sublethally (550 cGy) irradiated 2-month-old male NOD recipients

\begin{tabular}{|c|c|c|c|c|c|c|}
\hline $\begin{array}{l}\text { Group } \\
\text { No. }\end{array}$ & $\begin{array}{l}\text { Source of } \\
\text { lymph node and } \\
\text { spleen cells }\end{array}$ & $\begin{array}{l}\text { Cell inoculum } \\
\text { size }\end{array}$ & $\begin{array}{l}\text { Number of } \\
\text { recipients }\end{array}$ & $\begin{array}{l}\text { Linomide } \\
\text { therapy }\end{array}$ & $\begin{array}{l}\text { Number of diabetic } \\
\text { mice }(\%) \text { at } 90 \text { days } \\
\text { post-transfer }\end{array}$ & $p$ value $^{d}$ \\
\hline $\bar{A}$ & Diabetic $^{a}$ & $20 \times 10^{6}$ & 13 & - & $12(92)$ & - \\
\hline B & Diabetic & $30 \times 10^{6}$ & 5 & - & $5(100)$ & - \\
\hline $\mathrm{C}$ & $\mathrm{T}$ cells from diabetic & $20 \times 10^{6}$ & 6 & - & $6(100)$ & - \\
\hline $\mathrm{D}$ & Linomide treated & $20 \times 10^{6}$ & 11 & - & $0(0)$ & $<0.0001$ \\
\hline $\mathrm{E}$ & Diabetic & $20 \times 10^{6}$ & 5 & $+^{\mathrm{b}}$ & $5(100)$ & NS \\
\hline $\mathrm{F}$ & Diabetic & $30 \times 10^{6}$ & 6 & $t^{\mathrm{b}}$ & $6(100)$ & NS \\
\hline G & Diabetic & $20 \times 10^{6}$ & 9 & $++^{\mathrm{c}}$ & $2(22)$ & $<0.0015$ \\
\hline $\mathrm{H}$ & $\begin{array}{l}\text { Co-transfer } \\
\text { Diabetic } \\
\text { Linomide treated }\end{array}$ & $\begin{array}{l}20 \times 10^{6} \\
20 \times 10^{6}\end{array}$ & 7 & - & $6(86)$ & NS \\
\hline I & $\begin{array}{l}\text { Diabetic } \\
\text { Linomide treated }\end{array}$ & $\begin{array}{l}20 \times 10^{6} \\
40 \times 10^{6}\end{array}$ & 9 & - & $4(44)$ & $<0.0337$ \\
\hline $\mathrm{J}$ & $\begin{array}{l}\text { Diabetic } \\
\text { Non-diabetic }\end{array}$ & $\begin{array}{l}20 \times 10^{6} \\
40 \times 10^{6}\end{array}$ & 7 & - & $7(100)$ & - \\
\hline
\end{tabular}

${ }^{a}$ Aliquots of $20-30 \times 10^{6}$ cells were obtained from 30-week-old diabetic or age-matched Linomide-treated $(0.5 \mathrm{mg} / \mathrm{ml})$ female NOD mice and injected i.v. into male recipient mice 1 day after irradiation. ${ }^{b}$ Adoptive male recipients were put on Linomide $(0.5 \mathrm{mg} / \mathrm{ml})$ starting one day after the cell transfer. ${ }^{c}$ Adoptive male recipients were treated with the Linomide $(0.5 \mathrm{mg} / \mathrm{ml})$ for 10 weeks prior to cell transfer ${ }^{\mathrm{d}}$ Comparison

donors, in recipients receiving cell mixtures from both diabetic and Linomide-treated donors and the activity of the drug when given after the onset of insulitis all indicate that Linomide presumably generates immune cells capable of active suppression of the beta-cell directed immune response.

Treatment of NOD mice with various agents associated with macrophage activation, such as Bacillus Calmette Guerrin (BCG) [14] and complete Freund's adjuvant [15-18] result in marked amelioration of diabetes. Conversely, it has recently been shown that defects of macrophage differentiation and function are present in NOD mice [19]. Linomide has been found to have a profound immunostimulatory effect on macrophages of $\mathrm{BALB} / \mathrm{c}$ mice [4] and in preliminary experiments we have observed an increase in the Mac-3/Mac-1 expression ratio on NOD peritoneal cells obtained from mice treated with the drug, indicating a possible effect on activation and maturation of macrophage phenotype (unpublished observations). Thus, Linomide might prevent generation of anti-"self" responses by either enhancing APC-mediated tolerogenic responses, or alternatively by down regulating anti-"self" responses through macrophage dependent suppression signals, a phenomenon that was previously described as "suppressor macrophage" activity [14].

TNF- $\alpha$ has disparate effects on beta-cell function that are dependent on the mode of administration. On the one hand, TNF- $\alpha$ adversely modifies adhe- of groups $\mathrm{D}, \mathrm{E}, \mathrm{F}$ and $\mathrm{G}$ to group $\mathrm{A}$; groups $\mathrm{H}$ and $\mathrm{I}$ to group $\mathrm{J}$, Fisher's exact test. Diabetes was ascertained on the basis of two consecutive determinations of glucosuria. In adoptive recipients of cells from diabetic donors, glucosuria usually appeared between days $20-60$ post cell transfer; the cumulative incidence of diabetes was assessed 90 days after the procedure

sion properties of pancreatic beta cells [20] and potentiates the in vitro beta-cell cytotoxic effect of IL-1 [21] and interferon $-\gamma[22,23]$. On the other hand, systemic administration of TNF- $\alpha$ to NOD mice results in marked amelioration of diabetes [24]. Recently, it has been shown that TNF- $\alpha$ is produced selectively by pancreatic beta cells in response to exposure to IL-1 $\beta$ [25], thus possibly contributing to the selective destruction of beta cells in IDDM. Since Linomide has a marked inhibitory effect on exotoxin-induced TNF- $\alpha$ production in mice [26], an additional mode of drug action might be suppression of endogenous production of TNF- $\alpha$ by NOD beta cells. This possibility is currently under investigation in our laboratory.

In view of the fact that the beta-cell antigen(s) involved in initiation of the autoimmune response are unknown, direct in vitro documentation of antigenspecific anergy is currently not feasible. However, in experiments done in parallel in experimental autoimmune encephalomyelitis (EAE) in SJL/J mice we have recently documented Linomide-induced unresponsiveness to myelin basic protein, the antigen responsible for induction of the disease, while antigen non-specific T-cell responses to Con A and PHA, as in Linomide-treated NOD mice, were not affected [8]. Taken together, our data suggest that Linomide therapy results in re-induction of tolerance to betacell components that serve as immunogens for autoreactive cells, thus preventing or ameliorating autoimmune insulitis and diabetes, depending on the 
stage of disease at which therapy was instituted. Regardless of the mechanism involved, once unresponsiveness was established, lymphocytes obtained from Linomide-treated normoglycaemic donors failed to transfer the disease by adoptive transfer experiments.

From our studies, it is evident that complete protection of female NOD mice from diabetes for over 42 weeks can be conferred by a limited period of treatment at the onset of the disease (weeks 5 to 10), without the decrease in body weight observed in the chronically-treated animals (data not shown). Moreover, treatment at a dose of $0.5 \mathrm{mg} / \mathrm{ml}$ within this brief therapeutic window is more protective than chronic treatment with lower doses of the drug for the duration: IPGTTs performed at 42 weeks in the various dosage groups (Table 1 ), revealed a progressive impairment of glucose tolerance with reduction of drug dosage, whereas glucose tolerance in the limited treatment group was normal and comparable to that of the chronic $0.5 \mathrm{mg} / \mathrm{ml}$ group (data not shown).

Linomide, which is orally absorbed and devoid of any major side effects in experimental animals and man [27], might be a useful drug for treatment of IDDM at early stages of the disease, because it apparently suppresses autoreactivity, even in NOD mice with established insulitis, without causing gross immunosuppression.

Acknowledgements. We thank Dr. D.M. Karussis for helpful discussions and Dr. S. Morecki for performing some of the mitogen response experiments. This project was supported in part by grants from Pharmacia, the Hebrew University-Hadassah Diabetes Center and the Juvenile Diabetes Foundation International (to S. S.).

\section{References}

1. Kalland T, Alm G, Standhalske T (1985) Augmentation of mouse natural killer cell activity by LS 2616, a new immunomodulator. J Immunol 134:3956-3961

2. Kalland $\mathrm{T}$ (1990) Regulation of natural killer progenitors. Studies with a novel immunomodulator with distinct effects at the precursor level. J Immunol 144:4472--4476

3. Stalhandske T, Kalland T (1986) Effects of the novel immunomodulator LS 2616 on the delayed-type hypersensitivity reaction to Bordetella pertussis in the rat. Immunopharmacology $11: 87-92$

4. Larson EL, Joki A, Standhalske T (1987) Mechanisms of action of the new immunomodulator LS2616 on T-cell responses. Int J Immunopharmacol 9:425-431

5. Tarkowski A, Gunnarsson K, Stalhandske T (1986) Effects of LS-2616 administration upon the autoimmune disease of $(\mathrm{NZB} \times \mathrm{NZW})$ F1 hybrid mice. Immunology 59:589594

6. Tarkowski A, Gunnarsson K, Nilsson LA, Lindholm L, Stalhandske $T$ (1986) Successful treatment of autoimmunity in MRL/1 mice with LS-2616, a new immunomodulator. Arthr Rheum 29:1405-1409

7. Bjork J, Klienau S (1989) Paradoxical effects of LS-2616 (Linomide) treatment in the type II collagen arthritis model in mice. Agents and Actions 27:319-321

8. Karussis DM, Lehmann D, Slavin S et al. (1993) Successful treatment of chronic-relapsing experimental autoimmune encephalomylitis by the synthetic immunomodulator linomide (quinoline-3-carboxamide). Proc Natl Acad Sci USA 90:64006404

9. Charlton B, Bacelj A, Mandel TE (1988) Administration of silica particles or anti-Lyt2 antibody prevents beta-cell destruction in NOD mice given cyclophosphamide. Diabetes 37:930935

10. Slavin S, Strober S, Fuks Z, Kaplan HS (1977) Induction of specific tissue transplantation tolerance using fractionated total lymphoid irradiation in adult mice: long-term survival of allogeneic bone marrow and skin grafts. J Exp Med 146:34-48

11. Weiss L, Kedar E, Weigensberg M, Slavin S (1982) Natural cell-mediated cytotoxicity in mice treated with total lymphoid irradiation (TL1). Cell Immunol 70:188-195

12. Slavin S, Strober S (1979) Induction of allograft tolerance after total lymphoid irradiation (TLI): development of suppressor cells of the mixed leukocyte reaction (MLR). J Immunol 123:942-946

13. Tarcic N, David CS, Naor D (1989) Auto-delayed-type hypersensitivity induced in immunodeficient mice with modified self antigens. Immunology 67:184-190

14. Yagi H, Matsumoto M, Suzuki S et al. (1991) Possible mechanism of the preventive effect of BCG against diabetes mellitus in NOD mouse. I. Generation of suppressor macrophages in spleen cells of BCG-vaccinated mice. Cell Immunol 138:130 141

15. Sadelain MW, Qin HY, Lauzon J, Singh B (1990) Prevention of type I diabetes in NOD mice by adjuvant immunotherapy. Diabetes 39:583-589

16. McInerney MF, Pek SB, Thomas DW (1991) Prevention of insulitis and diabetes onset by treatment with complete Freund's adjuvant in NOD mice. Diabetes 40:715-725

17. Ulaeto D, Lacy PE, Kipnis DM, Kanagawa O, Unanue ER (1992) A T-cell dormant state in the autoimmune process of nonobese diabetic mice treated with complete Freund's adjuvant. Proc Natl Acad Sci USA 89:3927-3931

18. Qin H-Y, Sadelain MWJ, Hitchon C, Lauzon J, Singh B (1993) Complete Freund's adjuvant-induced T cells prevent the development and adoptive transfer of diabetes in nonobese diabetic mice. J Immunol 150:2072-2080

19. Serreze DV, Gaskins HR, Leiter EH (1993) Defects in the differentiation and function of antigen presenting cells in NOD/ It mice. J Immunol 150:2534-2543

20. Cirulli V, Halban PA, Rouiller D (1993) Tumor necrosis factor$\alpha$ modifies adhesion properties of rat islet $B$ cells. J Clin Invest 91:1868-1876

21. Mandrup-Poulsen T, Bendtzen K, Dinarello CA, Nerup J (1987) Human tumor necrosis factor potentiates human interleukin-1-mediated rat pancreatic $\beta$-cell cytotoxicity. J Immunol 139:4077-4082

22. Campell IL, Iscalo A, Harrison LC (1988) IFN- $\gamma$ and tumor necrosis factor- $\alpha$ : cytotoxicity to murine islets of Langerhans. $\mathbf{J}$ Immunol 141:2325-2329

23. Pukel C, Baquerizo H, Rabinovitch A (1988) Destruction of rat islet cell layers by cytokines: synergistic interactions of interferon- $\gamma$, tumor necrosis factor, lymphotoxin and interleukin-1. Diabetes 37:133-136

24. Jacob CO, Aiso S, Michie SA, McDevitt HO, Acha-Orbea $\mathrm{H}$ (1990) Prevention of diabetes in nonobese diabetic mice by tumor necrosis factor (TNF): similarities between TNF-alpha and interleukin. 1. Proc Natl Acad Sci USA 87:968-972

25. Yamada K, Takane N, Otabe S, Inada C, Inoue M, Nonaka K (1993) Pancreatic $\beta$-cell-selective production of tumor necrosis-alpha induced by interleukin-1. Diabetes 42:1026-1031

26. Gonzalo JA, Gonzalez- Garcia A, Kalland T, Hedlund G, Martinez-A C, Kroemer G (1993) Linomide, a novel immunomodulator that inhibits death in four different models of septic shock. Eur J Immunol 23:2372-2374

27. Bengtsson M, Simonsson B, Carlsson K et al. (1992) Stimulation of NK cell, $\mathrm{T}$ cell, and monocyte functions by the novel immunomodulator Linomide after autologous bone marrow transplantation. A pilot study in patients with acute myeloid leukemia. Transplantation 53:882-888 